\title{
A New M-type of Group A Streptococcus of Clinical Importance in Pyoderma and Pharyngitis
}

\author{
By H. C. DILLON, Jun., C. W. DERRICK \\ AND PATRICIA E. GOOCH \\ Department of Pediatrics, University of \\ Alabama School of Medicine, and The Children's Hospital, \\ Birmingham, Alabama 35294, U.S.A.
}

(Received 2 April 1975; revised 3 June 1975)

\begin{abstract}
SUMMARY
A new M-type of group A streptococcus, provisionally designated type 65, is described. The vaccine and other initially isolated strains of this type attracted attention because of the T-agglutination reactions $2 / 25$, not previously encountered among pyoderma streptococci. The investigations characterizing the strains as members of a new type were done with streptococci isolated from patients with pyoderma. However, type 65 was subsequently found to cause both pyoderma and acute pharyngitis.

The T-2 agglutination reactions encountered with original members of this type, plus the cross-reactions later seen with type 65 antiserum and M-type 2 streptococci, prompted a comparison of this new type with M-type 2 streptococci, including those with the T-2 agglutination and others with the 8-25-Imp.I9 complex. The two $M$-antigens were clearly distinguished from one another in reciprocal bactericidal and precipitin tests with absorbed antisera. They were further distinguished in that all type 65 strains were opacity-factor (OF) negative, whereas type 2 streptococci were uniformly OF-positive. Most M-type 65 strains subsequently found in surveillance studies were shown to be members of the 8-25-Imp.I9 T-complex. Type 65 is thus a newly described type which shares with M-types 55 and 57 a common T-agglutination pattern and, like members of these types, fails to produce opacity factor. In our collection of strains, from both pyoderma and pharyngitis, shown to be members of the 8-25-Imp.I9 complex, and OF-negative, only type 65 has been identified to date. In contrast to types 55 and 57 , the new type 65 does not appear to be of major importance in causing acute glomerulonephritis.
\end{abstract}

\section{INTRODUCTION}

A number of new streptococcal M-serotypes have been described in recent years. These have largely come from studies of pyoderma and acute glomerulonephritis (Top et al. 1967; Potter et al. 1968; Parker et al. 1968; Dillon, 1972; Dillon \& Dillon, 1974). Improved ability to identify M-antigens of pyoderma strains of group A streptococci has led to a better understanding of the epidemiology of acute glomerulonephritis and of the relationship between streptococcal M-serotypes and the clinical site of infection (Wannamaker, 1970; Dillon \& Derrick, 1974). However, a considerable proportion of streptococci from diverse clinical sources remain M-non-typable (Dillon, Derrick \& Dillon, 1974; Köhler, 1974).

The finding of M-non-typable streptococci with unusual or previously unrecognized combinations of $\mathrm{T}$-agglutination reactions indicates the appearance of a new M-serotype (Dillon \& Dillon, 1974). Such a type, provisionally designated M-65, that appears to be 
a cause of both pyoderma and acute pharyngitis, is described. The unexpected combination of agglutination reactions with T-2 and T-25 antisera, observed first with strains from patients with pyoderma, prompted studies leading to the identification of this new type.

\section{METHODS}

Clinical methods. These, as employed in the Streptococcal Infections Clinic, The Children's Hospital, were described previously (Dillon et al. 1967; Dillon, 1968; Dillon \& Derrick, I974). Group A streptococci now reported were isolated from I 28 patients with pyoderma and 253 patients with pharyngitis, seen between June 1970 and December 1972 at The Children's Hospital Outpatient Clinic, Birmingham, Alabama. Only initial isolates were examined.

Isolation and classification of group A streptococci. Methods routinely employed in this laboratory for the isolation and identification of group A streptococci have been described in detail (Dillon et al. 1967; Dillon \& Dillon, 1974). Serological grouping was by the capillary precipitin method (Lancefield, 1933). Procedures for serotyping were as follows: strains were examined by the T-agglutination method (Griffith, I934); acid extracts were then examined by the capillary precipitin method (Swift, Wilson \& Lancefield, 1943) or the micro-immunodiffusion method (Rotta et al. 197I). The initial battery of M-antisera employed was chosen on the basis of $\mathrm{T}$-agglutination typing results; all remaining M-non-typable strains were further examined with the full set of $\mathbf{M}$-antisera.

Group A streptococci examined. Group A streptococci, forming the major collections in this study, included 197 isolates from patients with pyoderma ( 128 from skin lesions and 69 others concomitantly isolated from the nose or throat) and 253 isolates from patients with acute pharyngitis. All strains were agglutinated by one or more of the T-antisera, 2, 8, 25 and Imp. I9. Three T-agglutination patterns emerged. The patterns studied included: T-2/25, that found with the original vaccine strains $5228-\mathrm{S}$ and $5654-\mathrm{S}$, which were isolated from pyoderma lesions; T-25 and other members of the 8/25/Imp. 19 complex, which included all strains agglutinated by Imp.I 9 antiserum, plus or minus reactions with T-8 and T-25. All were M-non-typable with the reference $M$-antisera available at the time of their initial isolation.

A collection of strains from previous studies of pyoderma and acute glomerulonephritis, including M-type 2, T-8/25/Imp.I9 strains ('Alabama 2') and M-49, was used (Dillon, Maxted \& Reeves, I968; Dillon et al. 1974). Selected M-non-typable strains with Tagglutination patterns unrelated to those just described were also used in testing newly prepared M-antisera.

Reference M-type strains I-6, 8, 9, I I-I 5, I 7-I 9, 22-27, 29-33, 36-44, 46-49 and 5I-58 were obtained from the Center for Disease Control, Atlanta, Georgia, U.S.A. M-type strains 59-6I were those originally isolated in this laboratory.

Reference antisera. Reference antisera for T-agglutination and M-precipitin tests were obtained from the Center for Disease Control. The standard set of T-agglutination antisera included the following pools and individual T-antisera: ' $T$ ' pool - I, 3, I3, B3264; ' $U$ ' pool-2, 4, 6, 28; ' $W$ ' pool - 5, I I, I 2, 27, 44; ' $X$ ' pool - 8, I4, 25, Imp. I9; ' $Y$ ' pool - I 5, I 7, 22, 23, 47; ' $Z$ ' pool -9 , I 8, I9, 30. A set of T-agglutination antisera provided by the Central Public Health Laboratory, Colindale, London (courtesy of Dr M. T. Parker and Dr W. R. Maxted) was employed in this laboratory for further examination of certain strains, including those initially T-non-typable or those with unusual $\mathrm{T}$-agglutination patterns. T-agglutination antisera for M-types 59 and 60 were prepared in this laboratory.

M-antisera from the Reagents Division, Center for Disease Control, included those for 
M-types I to $6,8,9$, I I to I 5, I 7 to I9, 22 to 33,36 to 44,47 to 49 , and 5 I. M-antisera for types 52 to 57 were kindly provided by Dr R. Facklam, Streptococcal Laboratory, Center for Disease Control. Additional M-antisera obtained from Dr Rebecca C. Lancefield, Rockefeller University, New York, N.Y., U.S.A., included those for M-types 2, 4, 24, 25, 26, 28, 29, 46, 48 and 57. M-antisera for M-types 2, 49, 59, 60 and 6I were prepared in this laboratory.

Initial serotyping was done with freshly isolated strains. Cultures were then stored at $-70^{\circ} \mathrm{C}$.

Detection of opacity factor. Tests for production of the serum OF were done by the serum-agar slide method (Maxted, Widdowson \& Fraser, 1974). Horse serum was used as the substrate. Culture supernatants from Todd-Hewitt broth cultures, grown overnight at $37^{\circ} \mathrm{C}$, were spotted on to the agar surface with a $4 \mathrm{~mm}$ loop and the slides incubated overnight at $37^{\circ} \mathrm{C}$ in a moist chamber. Positive reactions appeared as a distinct opaque area at the site of application of the supernatant.

Preparation of $M$-antisera. The vaccines used for the preparation of $\mathrm{M}$-antisera were produced by conventional methods (Moody et al. 1965). Strains for absorption were selected after a suitable precipitin titre was reached and cross-reactions were identified. Antisera were kept at $-4{ }^{\circ} \mathrm{C}$ and suitable lots subsequently lyophilized.

Bactericidal tests. Direct and indirect bactericidal tests were performed as described by Lancefield (1957). Heated, unabsorbed antisera were used in the indirect test. Colony counts were done with a Quebec counter (Spencer, American Optical Co., Buffalo, New York) and reported as the number of colony-forming units (c.f.u.); plates with complete or with extensive haemolysis (> IO00 c.f.u.) were designated 'laked' (L) or 'partially laked' (PL), respectively.

\section{RESULTS}

During epidemiological studies of pyoderma in 1970,27 strains were elassified in our laboratory as T-2/25, M-non-typable. The subsequent recognition of similar strains among patients with pharyngitis as well as pyoderma prompted a re-examination of this collection with several $\mathrm{M}$-antisera. We chose those representative of types known to share certain T-agglutination reactions common to ' $\mathrm{T}-2 / 25$ ' strains. None of them was typable with the M-antisera then in use for M-types $2,8,25,55$ and 57 . We proceeded to examine the possibility that these strains were thus representative of a new M-serotype.

\section{Identification of the new type}

Seven pyoderma strains with the T-2/25 agglutination pattern were randomly selected and examined in the direct bactericidal test to detect evidence of $\mathrm{M}$-antigen. All of them grew well. Brisk T-agglutination reactions with both T-2 and T-25 antisera persisted and all seven remained M-non-typable. Two strains, 5228-s and 5654-s, were chosen for the preparation of $\mathrm{M}$-antigen vaccines; suitable $\mathrm{M}$-antisera were raised in rabbits. Reciprocal capillary precipitin and micro-immunodiffusion tests with acid extracts of strains 5228-s and 5654 -S and their respective homologous $\mathrm{M}$-antisera, proved the two strains to have an identical $\mathrm{M}$-antigen. Reciprocal bactericidal tests further confirmed a common $\mathrm{M}$ antigen for the two vaccine strains (Table I). Antiserum prepared with strain 5654-s proved the better, hence strain 5654-S was selected as the reference type strain. Subsequent results reported here were obtained with this antiserum.

Strain 5654-S antiserum contained little group A antibody; that present was removed by absorption with group A, type 6 ('glossy') cells. Strong $(>4+)$ capillary precipitin reactions were obtained with the absorbed antiserum and acid extracts of both vaccine 
Table I. Reciprocal indirect bactericidal tests with strains 5228-s and 5654-S

\begin{tabular}{|c|c|c|c|c|}
\hline \multirow{2}{*}{$\begin{array}{c}\text { Strains } \\
\text { (T-agglutination patterns) }\end{array}$} & \multirow[b]{2}{*}{ Samples } & \multicolumn{3}{|c|}{$\begin{array}{l}\text { Number of c.f.u. at a bacterial } \\
\text { dilution of: }\end{array}$} \\
\hline & & $10^{-4}$ & $10^{-5}$ & $10^{-6}$ \\
\hline \multirow{2}{*}{$\begin{array}{l}5258-\mathrm{s} \\
(\mathrm{T}-2 / 25)\end{array}$} & Original inoculum & 317 & 47 & 5 \\
\hline & $\begin{array}{l}\text { After rotation with } \\
5228-\mathrm{s} \text { antiserum } \\
5654-\mathrm{s} \text { antiserum } \\
\text { Normal rabbit serum }\end{array}$ & $\begin{array}{c}368 \\
100 \\
L\end{array}$ & $\begin{array}{r}28 \\
9 \\
\text { PL }\end{array}$ & $\begin{array}{r}2 \\
0 \\
90\end{array}$ \\
\hline \multirow[t]{4}{*}{$\begin{array}{l}5654-\mathrm{s} \\
(\mathrm{T}-2 / 25)\end{array}$} & $\begin{array}{l}\text { Original inoculum } \\
\text { After rotation with }\end{array}$ & 1000 & I 28 & 12 \\
\hline & 5654-s antiserum & 292 & 24 & $\circ$ \\
\hline & 5228-s antiserum & 800 & 66 & I5 \\
\hline & Normal rabbit serum & $\mathrm{L}$ & PL & 220 \\
\hline
\end{tabular}

Table 2. Reciprocal indirect bactericidal test with strains 5654-s, reference $M$-type 2, and 1076-s

No. of c.f.u., at stated dilutions in tests with:

\begin{tabular}{|c|c|c|c|c|c|c|c|c|c|}
\hline \multirow[b]{2}{*}{ Samples } & \multicolumn{3}{|c|}{$\underbrace{5654-s}$} & \multicolumn{3}{|c|}{ Ref. type M-2 } & \multicolumn{3}{|c|}{$\overbrace{}^{1076-s}$} \\
\hline & $10^{-4}$ & $10^{-5}$ & $10^{-6}$ & $10^{-4}$ & $10^{-5}$ & $10^{-6}$ & $1 \mathrm{O}^{-4}$ & $10^{-5}$ & $10^{-6}$ \\
\hline $\begin{array}{l}\text { Original inoculum } \\
\text { After rotation with }\end{array}$ & 368 & 39 & 8 & 300 & 88 & 18 & 324 & 90 & 20 \\
\hline 5654-S antiserum & 72 & 4 & 0 & PL & 600 & I96 & $\mathbf{L}$ & PL & 750 \\
\hline $\begin{array}{l}\text { Type-M-2 antiserum } \\
\text { (CDC) }\end{array}$ & 344 & 256 & 60 & 16 & 4 & I & 120 & 44 & 14 \\
\hline $\begin{array}{l}\text { Type-M-2 antiserum } \\
\text { (RCL) }\end{array}$ & - & 500 & 一 & - & 2 & - & - & 18 & - \\
\hline Normal rabbit serum & $\mathbf{L}$ & PL & 248 & $\mathrm{~L}$ & 800 & 228 & $\mathbf{L}$ & PL & 850 \\
\hline
\end{tabular}

Reference M-type 2, M2, T2; 1076-s, M-2, T-8/25/Imp.19; CDC, Center for Disease Control, Atlanta, Georgia; R.C.L., Dr Rebecca C. Lancefield. This antiserum was unabsorbed, and was used with one bacterial dilution only, $10^{-5}$.

strains and the five additional $\mathrm{T}-2 / 25$ strains previously tested in direct bactericidal tests. Capillary precipitin tests with acid extracts of all available known M-types (up to type 6I) revealed minor cross-reactions with extracts of the three M-types 2, 49 and 55. Extracts of several M-type 2 (T-8/25/Imp.19) and type 49 strains from our collection were also found to give $\mathrm{I}+$ precipitin reactions with the new antiserum. In micro-immunodiffusion tests with this antiserum, faint precipitin lines, non-identical to the homologous type, were seen only with extracts of M-type 2 strains. Absorption of the antiserum with M-type 2 cells eliminated all three heterologous $\mathbf{M}$-type cross-reactions.

Reciprocal indirect bactericidal tests were then done with strain 5654-s, an M-type 2, T-2 reference strain, and strain 1076-S, an M-type 2, T-8/25/Imp.I9 strain from our pyoderma-nephritis collection (Table 2). Enhancement of phagocytosis was limited to the homologous M-type with both 5654 -S and M-2 antisera. A similar reciprocal test was done with strain 5654-S and the type 49 reference strain; no cross-protection was demonstrated. The M-55 antiserum available proved unsuitable for a reciprocal bactericidal test but the type 55 reference strain was examined with 5654 -s antiserum; no evidence of enhancement of phagocytosis for this heterologous type could be demonstrated. The indirect bactericidal test results, plus precipitin tests with the absorbed anti-5654-s serum, 
Table 3. Prevalence of Provisional M-type 65 among strains from pyoderma and pharyngitis

No. of Provisional M-type 65 strains isolated from patients with

\begin{tabular}{|c|c|c|c|c|}
\hline \multirow{3}{*}{$\begin{array}{l}\text { T-agglutination } \\
\text { patterns }\end{array}$} & \multicolumn{3}{|c|}{ 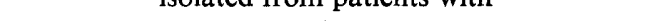 } & \multirow[b]{3}{*}{ Total* by type } \\
\hline & \multicolumn{2}{|c|}{ Pyoderma } & Pharyngitis & \\
\hline & Skin lesions & Nose or throat & Throat & \\
\hline $\mathrm{T}-2 / 25$ & $19 / 25(76)$ & $11 / 15(73)$ & $10 / 15(67)$ & $40 / 55(73)$ \\
\hline $\mathrm{T}-25$ & $16 / 28(57)$ & $8 / 12(67)$ & $16 / 103(16)$ & $40 / 143(28)$ \\
\hline 8/25/Imp.I9 & $58 / 75(77)$ & I $2 / 42(29)$ & $30 / 135(22)$ & $100 / 252(40)$ \\
\hline Total by site & $93 / 128(73)$ & $31 / 69(45)$ & $56 / 253(22)$ & \\
\hline
\end{tabular}

* Expressed as proportions, followed by the percentage in parentheses.

were evidence that strain 5654-S represented a new M-serotype. These findings were confirmed by both the Streptococcal Reference Laboratory, NCDC, Atlanta, Georgia, U.S.A. and the Streptococcus and Staphylococcus Reference Laboratory, Central Public Health Laboratory, Colindale, London. The new type was designated Provisional M-65.

\section{Prevalence of Provisional M-type 65 among collections of strains from pyoderma and pharyngitis}

Acid extracts of the group A streptococci listed in clinical methods were examined with the absorbed anti-5654-s serum. With the exception of the 27 pyoderma isolates first examined (those with the T-2/25 pattern), M-tests were performed by the micro. immunodiffusion method. Extracts which gave faint or indistinct precipitin lines were re-examined by capillary precipitin tests and considered M-positive only if confirmed by the latter method. Results are shown in Table 3; data are arranged to illustrate members of the new type in relation to clinical source and initial T-agglutination pattern. Most strains with a T-agglutination pattern identical to that of the vaccine strains were M-positive with the new antiserum; however, M-positive reactions were not limited to this particular group. The new type was predominant among the pyoderma strains. Although less common than in pyoderma, type 65 was also prevalent among strains from patients with pharyngitis.

In addition to examining 'related' strains (Table 3), M-non-typable wild-type strains that did not react with $\mathrm{T}$-antisera $8 / 25 / \mathrm{Imp}$. I9 were also examined; 25 pyoderma strains from each of the following T-agglutination types or complexes were all M-negative: T-3/I3/B3264, T-5/27/44, T-I I, T-I 2, T-II/I2, T-4, T-4/28 or T-28. Similar numbers of strains from patients with pharyngitis, found to agglutinate with T-3/I3/B3264, T-I I, T-I 2 and T-II/I2, were also examined and failed to react with 5654-S antiserum. We also examined acid extracts of reference strains used for the preparation of $\mathrm{T}$-agglutination antisera; none were found to precipitate with the new $\mathrm{M}$-antiserum. Thus, positive $\mathrm{M}$ reactions with 5654-S antiserum were limited to group A streptococci with the T-agglutination patterns shown in Table 3.

\section{Opacity factor reactions}

Opacity factor is an enzyme consistently produced by all members of certain M-serotypes, and is absent from all members of the remainder (Maxted et al. 1973). We previously found that all members of M-type 2, T-8/25/Imp.19, those strains commonly found in patients with pyoderma and nephritis, were OF-positive. The group A streptococci reported 


\section{Table 4. Opacity factor reactions}

Isolates from pyoderma patients (skin, nose, throat) are combined and listed as pyoderma strains.

\begin{tabular}{|c|c|c|c|}
\hline \multirow[b]{2}{*}{$\begin{array}{l}\text { T-agglutination } \\
\text { patterns }\end{array}$} & \multirow[b]{2}{*}{ Clinical category } & \multicolumn{2}{|c|}{ No. of UF-positive strains among } \\
\hline & & $\begin{array}{l}\text { All strains } \\
\text { examined }\end{array}$ & $\begin{array}{c}\text { Provisional } \\
\text { M-type } 65 \\
\text { strains }\end{array}$ \\
\hline $\mathrm{T}-2 / 25$ & $\begin{array}{l}\text { Pyoderma } \\
\text { Pharyngitis }\end{array}$ & $\begin{array}{l}0 / 40(0) \\
0 / 15(0)\end{array}$ & $\begin{array}{l}0 / 30(0) \\
0 / 10(0)\end{array}$ \\
\hline $\mathrm{T}-25$ & $\begin{array}{l}\text { Pyoderma } \\
\text { Pharyngitis }\end{array}$ & $\begin{array}{c}5 / 40(12) \\
23 / 103(22)\end{array}$ & $\begin{array}{l}0 / 24(0) \\
0 / 17(0)\end{array}$ \\
\hline 8/25/Imp.19 & $\begin{array}{l}\text { Pyoderma } \\
\text { Pharyngitis }\end{array}$ & $\begin{array}{l}14 / 1117 \text { (12) } \\
63 / 135(47)\end{array}$ & $\begin{array}{l}0 / 70(0) \\
0 / 30(0)\end{array}$ \\
\hline Total & & $105 / 450(23)$ & $0 / 18 \mathrm{I}(0)$ \\
\hline
\end{tabular}

here were also tested for production of OF (Table 4). Positive and negative controls, respectively, were provided by M-type 2 and M-type 12 streptococci. All members of the new M-type were OF-negative. In addition, the 15 remaining strains (ten from pyoderma and five from pharyngitis) identified by T-agglutination as T-2/25, but found M-non-typable, were also OF-negative.

Most pyoderma strains examined, whether or not found to be members of type 65 , were OF-negative (Table 4). Opacity factor-positive reactions were most often encountered among M-non-typable strains from patients with pharyngitis, identified by T-agglutination as members of the $8 / 25 / \mathrm{Imp} .19$ pattern. During subsequent epidemiological studies, a number of type 8 streptococci were identified with a new batch of $\mathrm{M}$-antiserum, and all were also found to be OF-positive. This prompted a re-examination of the previously M-non-typable strains listed in Table 4 . Ten of the 63 OF-positive strains (8/25/Imp.19) from patients with pharyngitis reacted with this type 8 antiserum, but none of the OFnegative strains and none from patients with pyoderma so reacted.

\section{DISCUSSION}

Classical M-type 2 streptococci are those agglutinated by the corresponding T-antiserum, T-2, and are characterized as M-2, T-2 by major reference laboratories (Maxted, 1953). Throughout our extensive studies of pyoderma and acute glomerulonephritis, we have not encountered such strains in skin lesions. Limited numbers of M-2, T-2 strains have been recovered from patients with acute pharyngitis seen in our Streptococcal Infections Clinic. In contrast, we have documented the importance of M-type 2 streptococci with T-reactions limited to the $8-25$-Imp.19 complex as a major cause of acute glomerulonephritis after pyoderma (Dillon et al. I968). This difference in the T-agglutination reactions of group A, M-type 2 streptococci, related to the site and clinical nature of the infection, has remained intriguing to us, especially because of the striking nephritogenic potential of the 'Alabama Type 2' pyoderma strains (Dillon et al. 1974). The finding of strains from skin lesions with the T-2 antigen thus provoked considerable interest in our laboratory.

The combination of T-reactions with T-2 and T-25 antisera in strains from pyoderma and pharyngitis suggested that they might represent yet another unusual antigenic variant of M-type 2, one capable of causing skin or throat infection. However, in neither case were the newly recognized strains associated with the development of acute glomerulo- 
nephritis, and repeated examination with different batches of M-2 antisera gave negative results. Negative tests for OF further indicated that they were different from M-type 2, since strains with the latter M-antigen are OF-positive. The preparation of a suitable M-antiserum clearly distinguished the new Provisional Type 65.

The T-2/25 agglutination reactions found with the vaccine and other originally isolated strains found to be members of Provisional Type 65, proved a useful laboratory tool for distinguishing between strains. However, strains with the $2 / 25$ pattern were no longer encountered after 197I. It is apparent from the reported results that most strains subsequently proved to be members of the new Provisional Type 65 were classified by T-agglutination as members of the 8-25-Imp. 9 complex. However, repeated examination of the strains originally attracting attention revealed a persistence of the T-2 agglutination reactions, and cross-reactions with unabsorbed Provisional M-65 antiserum and M-type 2 extracts suggest a possible related antigen common to types M-2 and Provisional 65.

We have continued to examine strains of group A streptococci, from both pyoderma and throat infections, isolated subsequent to the completion of this investigation. Although these recent epidemiological data are incomplete Provisional Type 65 strains have remained common in both skin and throat infections among our patients. A preliminary data analysis indicates that they were especially common in 1974; similar numbers of Provisional Type 65 and M-type 2 streptococci were isolated from patients with acute pharyngitis during that year. The latter strains were 'classical' M-type 2, T-2 streptococci and were all OF-positive. Agglutination reactions of Provisional M-65 strains were limited to the 8-25-Imp. I9 complex, and ali were OF-negative.

Maxted et al. (1974) recently demonstrated the usefulness of an antibody test for serum $\mathrm{OF}$, as a further means for serological classification of group A streptococci. Members of Provisional Type 65 are uniformly OF-negative and thus cannot be typed by this method. However, the determination of the test for $\mathrm{OF}$ is of material value in further characterizing group A streptococci. As noted, positive $\mathrm{OF}$ reactions further distinguished M-type 2 streptococci from Provisional Type 65 strains. On the basis of current knowledge, group A streptococci having in common the T-agglutination pattern $8 / 25 / \mathrm{Imp}$. I9 (or some components of this complex) can be further divided into OF-positive and OF-negative strains of known M-types (Maxted et al. 1974). Opacity factor-positive M-types include types 2, 25 and 58. M-type 8 has also been reported to be OF-positive (Bergner-Rabinowitz \& Ofek, 1974), and our results confirm this relationship. Opacity factor-negative types include types 55 and 57, and we now add the new Provisional Type 65 to this group. Types 55 and 57 , nephritogenic serotypes which have caused epidemics of pyoderma and nephritis in Trinidad (Parker et al. 1968), have not been found in our studies. A careful re-examination of the OF-negative strains reported in the present study failed to reveal members of either type. Thus, in our collection of both pyoderma and pharyngitis strains of group A streptococci classified as members of the 8-25-Imp.19 complex, and found to be OF-negative, Provisional Type 65 is the only M-type that we have as yet identified.

This research was supported in part by the United States Army Medical Research and Development Command, Department of the Army, under research contract No. DA-49 I93MD-2635, by research grant No. CC 00599 from the Center for Disease Control, Atlanta, Georgia, and by grant No. MC-R-oroog8 from the Maternal and Child Health Service. We gratefully acknowledge the technical support of Miss Ellen Moore, the clinical assistance of Mrs Marie Petry and Mrs Jenelle Jones, and the editorial assistance of Mrs Anna Sue Kimsey. 


\section{REFERENCES}

Bergner-Rabinowitz, S. \& OFEK, I. (1974). A typing scheme for Streptococcus pyogenes based on T-antigen and enzyme production properties: an epidemiological survey in Israel. In Streptococcal Disease and the Community, Proceedings of the Fifth International Symposium on Streptococcus pyogenes, pp. I9-25. Edited by M. J. Haverkorn. Amsterdam and New York: Excerpta Medica.

DilloN, H. C. (1968). Impetigo contagiosa: suppurative and non-suppurative complications. I. Clinical, bacteriologic and epidemiologic characteristics of impetigo. American Journal of Diseases of Children II5, 530-54I.

Dillon, H. C. (1972). Streptococcal infections of the skin and their complications: impetigo and nephritis. In Streptococci and Streptococcal diseases, pp. 572-586. Edited by L. W. Wannamaker and J. M. Matsen. New York and London: Academic Press.

Dillon, H. C. \& Derrick, C. W. (1974). Recent studies of streptococcal skin and throat infections in Alabama. In Streptococcal Disease and the Community, Proceedings of the Fifth International Symposium on Streptococcus pyogenes, pp. 266-274. Edited by M. J. Haverkorn. Amsterdam and New York: Excerpta Medica.

Dillon, H. C., Derrick, C. W. \& Dillon, M. S. (1974). M-antigens common to pyoderma and nephritis. Journal of Infectious Diseases 130, 257-267.

Dillon, H. C. \& Dillon, M. S. A. (1974). New streptococcal serotypes causing pyoderma and acute glomerulonephritis - types 59, 60 and 6I. Infection and Immunity 9, 1070-1078.

Dillon, H. C., Maxted, W. R. \& Reeves, M. S. (1968). Acute glomerulonephritis following skin infection due to streptococci of M-type 2. Lancet $\mathrm{i}, 543-545$.

Dillon, H. C., Moody, M. D., Maxted, W. R. \& Parker, M. T. (1967). The epidemiology of impetigo and acute glomerulonephritis. American Journal of Epidemiology 86, 710-723.

GrIfFITH, F. (1934). Serological classification of Streptococcus pyogenes. Journal of Hygiene 34, 542584 .

KöHLER, W. (1974). Results of the Second International Streptococcus pyogenes Type Distribution Survey. In Streptococcal Disease and the Community, Proceedings of the Fifth International Symposium cn Streptococcus pyogenes, pp. I0-13. Edited by M. J. Haverkorn. Amsterdam and New York: Excerpta Medica.

LANCEFIELD, R. C. (1933). A serological differentiation of human and other groups of streptococci. Journal of Experimental Medicine 57, 57I-595.

LANCEFIELD, R. C. (\$957). Differentiation of group A streptococci with a common R antigen into 3 serological types, with special reference to the bactericidal test. Journal of Experimental Medicine ro6, 525-544.

MAXTED, W. R. (I953). The M and T antigens of Streptococcus pyogenes type 2. Journal of Pathology and Bacteriology 65, 345-354.

Maxted, W. R., Widdowson, J. P. \& Fraser, C. A. M. (1974). Antibody to streptococcal serum opacity factor. In Streptococcal Disease and the Community, Proceedings of the Fifth International Symposium on Streptococcus pyogenes, pp. I 32-1 36. Edited by M. J. Haverkorn. Amsterdam and New York: Excerpta Medica.

Maxted, W. R., Widdowson, J. P., Fraser, C. A. M., Ball, L. C. \& Bassett, D. C. J. (I973). The use of the serum opacity reaction in the typing of group A streptococci. Journal of Medical Microbiology 6, 83-90.

Moody, M. D., Padula, J., Lizana, D. \& Hall, C. T. (I965). Epidemiologic characterization of group A streptococci by $\mathrm{T}$-agglutination and M-precipitation tests in the Public Health Laboratory. Health Laboratory Science 2, 149-162.

Parker, M. T., Bassett, D. C. J., Maxted, W. R. \& Arneaud, J. D. (I968). Acute glomerulonephritis in Trinidad: serological typing of group A streptococci. Journal of Hygiene 66, 657-675.

Potter, E. V., Moran, A. F., Poon-King, T. \& Earle, D. P. (1968). Characteristics of beta hemolytic streptococci associated with acute glomerulonephritis in Trinidad, West Indies. Journal of Laboratory and Clinical Medicine 71, I26-I37.

Rotta, J., Krause, R. M., Lancefield, R. C., Everly, W. \& Lackland, H. (197I). New approaches for the laboratory recognition of $\mathrm{M}$ types of group A streptococci. Journal of Experimental Medicine 134, I 298-I315.

SwifT, H. F., Wilson, A. T. \& Lancefield, R. C. (I943). Typing group A hemolytic streptococci by $M$ precipitin reactions in capillary pipettes. Journal of Experimental Medicine 78, 127-1 33 .

Top, F. H., Jun., Wannamaker, L. W., Maxted, W. R. \& Anthony, B. F. (1967). M antigens among group A streptococci isolated from skin lesions. Journal of Experimental Medicine 126, 667-685.

WanNamaker, L. W. (1970). Differences between streptococcal infections of the throat and of the skin. New England Journal of Medicine 282, 23-3I and 78-85. 